Title: Are deficits in cognition associated with psychotic-like experiences after cannabis?

Authors: Emma Barkus, BSc(Hons), $\mathrm{PhD}^{1}$, Paul Morrison, BSc(Hons), MbChB, MRCPsych, MSc, $\mathrm{PhD}^{2}$, Marta Di Forti, MD, MRCPsych, ${ }^{2}$ and Robin M Murray, MbChB, MRCP, MRCPsych, MD, MPhil, FRCP, FRCPsych, DSc, FMedSci, FRS ${ }^{2}$

${ }^{1}$ School of Psychology, University of Wollongong, Wollongong, NSW 2500. Australia.

${ }^{2}$ The Institute of Psychiatry, De Crespigny Park, Denmark Hill, London. SE5 8AF. United Kingdom. (Where the work was carried out.)

Running title: Cannabis experiences and cognition.

Key words: Cognition, cannabis, cannabis experiences, schizotypy.

\title{
Communicating Author:
}

Dr. Emma Barkus

Email: ebarkus@uow.edu.au

Telephone: $+61(0) 242218134$

Fax: $+61(0) 242214163$.

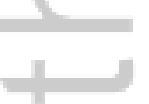

Acknowledgments: EB is currently funded by a Brain and Behaviour Research Foundation (formally NARSAD) Young Investigator Award. EB also receives in kind support from GW

This is the author manuscript accepted for publication and has undergone full peer review but has not been through the copyediting, typesetting, pagination and proofreading process, which may lead to differences between this version and the Version of Record. Please cite this article as doi: $10.1002 /$ hup. 2556 
Pharmaceuticals. We would like to acknowledge the contributions of Lindsay Smith, Rosa Michalczuk and Eliza Burton who collected some of the data reported in this paper.

Conflicts of Interest: None.

\section{Abstract:}

Objectives: Not all individuals who smoke cannabis report psychotic-like experiences. Given that risk factors for psychotic disorders are multifaceted, precipitating factors to psychoticlike experiences after cannabis are likely to be equally complex. Reduced neurocognitive performance is associated with both psychosis risk and cannabis use. Therefore it is possible cognitive performance may differentiate those who report psychotic-like experiences after cannabis from those who do not. We determined whether those reporting psychotic/dysphoric experiences after cannabis had reduced neurocognitive performance compared to those reporting primarily euphoric experiences.

Methods: Participants were recruited on the basis of responses to the cannabis high captured by the Psychosis-Dysphoric and Euphoric experiences subscales from the Cannabis Experiences Questionnaire (CEQ).

Results: Compared to participants reporting primarily euphoric cannabis experiences $(n=36$; $44 \%$ male; mean age $(\mathrm{SD})=28$ (9) years), those who reported psychotic/dysphoric experiences $(n=40 ; 45 \%$ male; mean age $(S D)=26(5)$ years) demonstrated significantly faster responses to a trial and error learning task. In the presence of distracters, those with psychotic/dysphoric experiences after cannabis made more errors on a Continuous Performance Task. 
Are deficits in cognition associated with psychotic-like experiences after cannabis?

Conclusions: Those who report psychotic/dysphoric experiences after cannabis have subtle inefficiencies in their cognitive processes. The multiple factors which predict vulnerability to psychotic-like experiences after cannabis require further investigation.

(200 words)
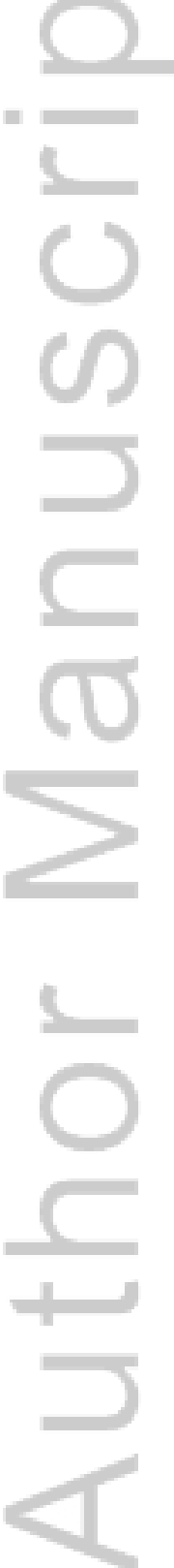

This article is protected by copyright. All rights reserved. 


\section{Introduction:}

Schizotypal traits (or schizotypy) are reported in excess in those at risk for developing psychosis and in relatives of patients with psychotic disorders (e.g. Keshavan et al 2008; Woods et al 2009). Furthermore, factors which exacerbate psychotic symptoms in patients with psychosis also increase the likelihood that those who score highly on schizotypy will report psychotic-like experiences (e.g. Mackie et al 2011; Rössler et al 2007; Stefanis et al 2004). One factor that exacerbates psychotic symptoms is cannabis use (e.g. van Os et al 2002). The nature of the relationship between cannabis and psychotic experiences is still a matter of debate. It has been hypothesized that the relationship could be based on recency of use (e.g. Hides et al 2009), dose-response (e.g. Ruiz-Veguilla et al 2013), or against a backdrop of other psychosis risk factors such as childhood trauma (e.g. Alemany et al 2014). Given that the factors which lead to psychotic disorders are complex, the likelihood is multiple biological and environmental factors also interact with cannabis use to lead to psychotic-like experiences.

There is growing interest in the experiences people have after using cannabis (e.g. Mason et al 2008; Davidson and Schenk 1994). In particular, it has been reported that those who score highly on schizotypy are more likely to report psychotic-like experiences as well as increased after (or persisting) effects once the cannabis high has abated (Barkus and Lewis 2008; Stirling et al 2008; Verdoux et al 2003). Schizotypal traits and a gene coding for an enzyme involved in the breakdown of dopamine, are both reported to mediate experiences after delta9-tetrahydrocannabinol ( $\Delta-9-\mathrm{THC}$; the psychomimetic compound in cannabis) administration 
Are deficits in cognition associated with psychotic-like experiences after cannabis?

of (Henquet et al 2006). However, these factors do not fully explain the variability in the experiences people report after cannabis use. This suggests other factors are involved in determining whether people have psychotic-like experiences after cannabis.

High schizotypes have similar cognitive deficits to those reported in patients with schizophrenia, although to a lesser degree (e.g. Brown and Cohen 2010; Johnson et al 2003; Suhr and Spitznagel 2001; Lenzenweger and Gold 2000). Additionally, schizotypal traits in relatives of patients with schizophrenia (aged during the risk period for developing psychosis) are related to cognitive deficits (Diwadkar et al 2006). Cognitive deficits are also associated with continued cannabis use in recreational and heavy users (e.g. Solowij et al 2002; Indlekofer et al 2009; McHale and Hunt 2008). Some authors have even suggested that the cognitive deficits in long term heavy cannabis users are an endophenotype for the deficits in patients with schizophrenia (Solowij and Michie 2007). Taken together these data suggest inefficient information processing is associated with both schizotypy and cannabis use (also see Mass et al 2001). Therefore, it may be that cognitive performance represents an additional factor involved in elevating the likelihood of psychotic experiences after cannabis.

In the current study, we recruited participants on the basis that they scored above the mean on the Psychosis-Dysphoric immediate subscale from the Cannabis Experiences Questionnaire (CEQ; Barkus et al 2006; Barkus and Lewis 2008; Stirling et al 2008). This measure was developed to systematically record the experiences people have had after smoking cannabis recreationally. We hypothesized that:- 
1) Those who reported more frequent psychotic/dysphoric experiences after cannabis would score higher on schizotypy and the after effects from cannabis when compared to those who have primarily euphoric experiences.

2) Those with psychotic/dysphoric experiences after cannabis will perform worse on measures of memory, learning and attention than those who have primarily euphoric experiences.

Method:

Participants

On the basis of the scores provided on the Euphoric and Psychosis-Dysphoric immediate experiences subscales from the CEQ (Barkus and Lewis 2008) participants were contacted for further testing. Participants were then selected into the Psychosis-Dysphoric group (High PD from here on) if they scored above the mean of 41. Participants were included in the Euphoric group (Control Group from here on) if they scored above the mean of 35 on the Euphoric experiences subscale and below 41 on the Psychosis-Dysphoric subscale. This method of group selection meant that the two groups only differed in whether they had psychosis/dysphoric experiences after cannabis (rather than having a control group who simply reported few to no subjective changes after cannabis).

In total 76 participants completed the neurocognitive assessment. There were 40 participants in the High PD group (45\% male; mean age $(\mathrm{SD})=26(5)$ years) and 36 in the Control group (44\% male; mean age $(\mathrm{SD})=28(9)$ years). 
Are deficits in cognition associated with psychotic-like experiences after cannabis?

\section{Materials}

Questionnaires

1. The development and properties of the CEQ have been described in detail elsewhere (e.g. Barkus et al 2006; Barkus and Lewis 2008). In brief, the CEQ captures both the immediate experiences which people have had with cannabis as well as the persisting after effects. The immediate experiences are considered those associated with the 'high' of cannabis. The Barkus and Lewis (2008) subscales for the CEQ produced two immediate experiences subscales of Psychosis-Dysphoric (e.g. Auditory hallucinations, Depressed, Disturbed in your thinking) and Euphoric (e.g. Being relaxed, Energized, Laid Back) experiences. The CEQ defines after effects as those subjective experiences attributed to cannabis use that occur once the high has abated and can last up to three days after having smoked cannabis. The after effects are separated into Amotivational (e.g. Have reduced attention, Slowing of time) and Psychosis-like After Effects (e.g. Paranoid without reason; Cannot remember events). Participants respond on a likert scale according to the frequency with which they have had the experiences listed. The CEQ also captures substance use in a structured format asking about current/past status, age of first use, frequency of use, and time of day used.

2. The Schizotypal Personality Questionnaire (SPQ; Raine 1991) is a standard measure of schizotypy containing 74-items based on the DSM-III-R criteria for schizotypal 
personality disorder (Raine, 1991). Participants respond Yes or No according to whether they endorse a behaviour or experience described. Items are summed into a total score and three dimensions: Cognitive Perceptual, Interpersonal and Disorganisation.

\section{Neurocognitive Testing}

1) Participants completed a number of neurocognitive tasks: National Adult Reading Test (NART; Nelson, 1982) was used to determine verbal intelligence. Participants read aloud the standardized list of atypically spelt words. The outcome variables were the number of errors made.

2) Trails A and B were used to capture basic processing speed. In Trails A participants used a pen to join dots which had been labelled in number order. Whilst for Trails B the dots were labelled with both numbers and letters, and participants needed to alternate between a letter and a number whilst maintaining sequential order. The time taken to complete each trail was taken as the outcome variable.

3) Verbal Fluency was assessed using letter fluency (with the letters F, A, and S), category verbal fluency and then a category switching task. In all instances participants were asked to verbalise as many words they could come up with in one minute for the relevant letter or category.

4) nback (e.g. Callicot et al 1998) was used as a measure of working memory. Outcome variables were correct responses, reaction time, errors and reaction time errors over the three levels of difficulty. 
Are deficits in cognition associated with psychotic-like experiences after cannabis?

5) Treasure Chests Spatial Working Memory (SWM; Smallman et al 2009) captured spatial working memory. An overall error score, number of choices and completion time were the main outcome variables for the three levels of difficulty of the task (four chests, six chests, eight chests).

6) AX-BY Continuous Performance Task (CPT; e.g. Frank et al 2007) was used as a measure of attention, the task was designed with sufficient difficulty that healthy volunteers would make errors on this task. The main outcome variables were correct responses to the four types of stimuli (AX, AY, BX, BY) and correct answer response time. In this task, letters appear one at a time in the middle of the screen. The letters are capitalised A's, X's, B's and Y's. Participants were told to respond to letters with a right mouse click, except when a letter $\mathrm{X}$ had been preceded by a letter $\mathrm{A}$ and then the response was a left mouse click. To increase the difficulty of the task on some trials lower case letters appeared in between the upper case letters, participants were asked to ignore these and make no response.

7) Spatial Trial and Error Learning Task (T\&E; e.g. Mehta et al 2005) was used to measure non-verbal learning. The number of correct responses and response time for correct answers of the two types of stimuli (Pairs and Non-Pairs) were used as the main outcomes over five sections of the timeline of the task.

\section{Procedure}

The project had ethical approval through South London and Maudsley NHS Ethics Committee as part of a larger project exploring neurocognitive, neurological, psychological 
and genetic factors associated with schizophrenia. Participants were compensated for their time.

Participants were initially contacted using email. Once they indicated an interest in taking part, participants were sent the initial questionnaires either electronically or in pen-and-paper format. Participants' scores on the Euphoric and Psychosis-Dysphoric subscales from the CEQ were examined to determine eligibility.

Suitable participants were emailed and a time was arranged for them to come into the Centre for Neuroimaging Sciences, Institute of Psychiatry to complete the neurocognitive testing in a quiet environment. Participants were screened using the Mini International Neuropsychiatric Interview (MINI; Sheehan et al 1997) to ensure they were not currently being treated for or displaying psychiatric symptoms. Task order was randomised across all participants.

\section{Statistical Analysis}

All statistical analysis was performed in Statistical Package for Social Sciences (SPSS) version 15. Many of the variables did not conform to a normal distribution. Therefore they were transformed using either a log or square root transformation. Untransformed and transformed data skewness and kurtosis values were then compared to determine whether there was a significant improvement in the data. If no improvement was achieved for ease of interpretation, untransformed data were used in the analysis, since parametric analyses are sufficiently robust to cope with minor violations of normality. Independent t-tests and 
Are deficits in cognition associated with psychotic-like experiences after cannabis?

ANOVAs were used to compare the groups of participants on their patterns of cannabis use and experiences after cannabis. Given that many of the tasks had multiple levels of difficulties, repeated measures ANOVAs were primarily used. Independent t-tests were used post hoc to determine where significant differences lay and also when the dependent variable only contained a single level. For all ANOVA results Greenhouse-Geisser corrected F values and degrees of freedom were used to correct for violations of sphericity. Data was not available for all participants on all tasks therefore sample sizes are given for each analysis.

\section{Results:}

In the interests of space descriptive statistics will only be presented for significant results.

\section{Participants}

The demographic characteristics and the questionnaire scores for the two groups of participants are displayed in Table 1.

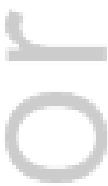

\section{INSERT TABLE 1 ABOUT HERE.}

The two groups of participants did not differ on demographic variables, NART errors, processing speed, or verbal fluency.

\section{i. Patterns of Substance use}


There was no association between CEQ group and the patterns of cannabis use; this meant the groups were matched on the basis of frequency of use, past/current cannabis users, time of day used and age of first use. There was a trend for participants in the High PD group not to have drunk alcohol $\left(\chi^{2}=3.08, \mathrm{df}=1\right.$, Fisher's exact correction $\left.\mathrm{p}=0.07\right)$. The four people who had not used alcohol were all in the High PD group. There were no significant differences between the two groups in terms of their exposure to recreational drugs. Given the trends on alcohol use we examined whether there was any association between the groups and current or past alcohol use; there was none. Since there were no group differences on recreational drug exposure Table 2 present this data for the sample as a whole.

\section{INSERT TABLE 2 ABOUT HERE.}

\section{Questionnaires}

\section{i. SPQ Scores}

There were no differences between the High PD group and controls on the SPQ dimensions or total score.

\section{ii. CEQ Subscales}

Next the group differences on the CEQ dimensions were examined. The two groups did not differ for Euphoric experiences ( $\mathrm{p}=0.115)$. The High PD group had significantly higher scores on the immediate Paranoid-Dysphoric Experiences $(\mathrm{t}(66.88)=9.89, \mathrm{p}<0.001)$, Amotivational After Effects $(\mathrm{t}(74)=3.86, \mathrm{p}<0.001)$ and Psychosis After Effects 
Are deficits in cognition associated with psychotic-like experiences after cannabis?

$(t(60.31)=5.49, p<0.001)$ when compared to the Controls. Therefore the two groups were equally likely to have euphoric experiences after cannabis but the High PD group were significantly more sensitive to the immediate psychotogenic effects of cannabis and after effects from cannabis use.

\section{Neurocognition}

\section{i. Treasure Chests SWM}

\section{Error Rates}

Main Effects of Task

An overall error score was calculated, combining both within and between search errors.

There was no main effect of group on the number of errors. There was a significant effect of level of difficulty $(\mathrm{F}(1.19,86.97)=32.25, \mathrm{p}<0.001)$, with the most errors being recorded on the eight treasure chests (mean=2.58, $\mathrm{SD}=3.52$ ), fewest in the four chests (mean $=0.11$, $\mathrm{SD}=0.36$ ) and six chests was an intermediary condition (mean=0.79, $\mathrm{SD}=1.39$ ).

\section{Effects of Participant Group}

There was no significant interaction between participant group and level of difficulty for the errors participants made.

\section{Completion Times}

Main Effect of Task 
For completion time there was a significant main effect of the levels of difficulty of the task $(\mathrm{F}(1.37,100.04)=448.62, \mathrm{p}<0.001$; means $(\mathrm{SD})$ Four chests: $1.21(0.16)$ mins; Six chests: 1.47 (0.08) mins; Eight chests: 1.68 (0.09) mins).

\section{Effects of Participant Groups}

There were no main effects or interactions with participant group.

\section{Number of Choices}

Main Effect of Task

The number of 'clicks' or choices participants made when searching for the coins are shown in Table 3. There was a main effect of difficulty $(F(1.21,88.15)=227.79, p<0.001)$, with the number of choices increasing in a linear fashion with task difficulty.

\section{Effects of Participant Groups}

There was also an interaction between participant group and level of difficulty $(\mathrm{F}(1.21$, 88.15)=2.91, $\mathrm{p}=0.04)$. At the Six Treasure Chests level the High PD group reported significantly fewer choices compared to the Controls $(\mathrm{t}(73)=3.28, \mathrm{p}=0.002)$.

\section{INSERT TABLE 3 ABOUT HERE.}

\section{ii. Nback}

This article is protected by copyright. All rights reserved. 
The descriptive statistics for significant analyses are displayed in Table 3. There were no group differences on the correct responses for the attention level, therefore this was not included as a covariate in subsequent analysis.

\section{Main Effect of Task}

The significant effects were for level of task difficulty with fewer correct responses $(\mathrm{F}(1.71$, $121.52)=70.36, \mathrm{p}<0.001)$, increasing reaction times $(\mathrm{F}(1.81,128.70)=69.44, \mathrm{p}<0.001)$ and increasing errors $(\mathrm{F}(1.67,118.75)=84.15, \mathrm{p}<0.001)$ related to increasing task difficulty.

\section{Effects of Participant Group}

There were no significant main effects or interactions with participant group. However, there was a trend for the High PD group (mean=459.29, $\mathrm{sd=91.40)} \mathrm{to} \mathrm{have} \mathrm{longer} \mathrm{reaction} \mathrm{times}$ than Controls (mean=425.02, $\mathrm{sd}=69.05)$ on the attention block of the task $(\mathrm{t}(71)=1.79$, $\mathrm{p}=0.078)$.

\section{iii. AX-BY CPT Task}

A multiple level repeated measures ANOVA was used to examine the effects of group on the AX-BY CPT $(n=57)$. There were two within subject variables, four levels of stimuli (AX, $\mathrm{AY}, \mathrm{BX}$ and BY) and two levels of distracter (Present and absent), the participant group was the between subject variable for both the accuracy and reaction time data. 


\section{Accuracy}

The estimated marginal means (and standard errors) for the number of correct responses are presented in Figure 1.

\section{Main Effect of Task}

There was a significant effect of stimuli but this is driven by the number of each type of stimuli $(\mathrm{F}(3,165)=172.25, \mathrm{p}<0.001$; means not reported $)$. The task altered participants' responding with distracters significantly decreasing accuracy (Distracters: 10.90 (0.35); Nondistracters: $11.14(0.33) ; \mathrm{F}(1,55)=28.82, \mathrm{p}<0.001)$, and the distracters had a more significant effect on the $\mathrm{AX}$ and $\mathrm{BX}$ stimuli $(\mathrm{F}(3,63.61)=11.13, \mathrm{p}=0.001)$.

\section{Effects of Participant Groups}

There was no main effect of participant group; nor was the interaction between participant group and stimuli significant. There was an interaction between participant group and distracter $(F(1,55)=4.70, p=0.034$, Figure $1 \mathrm{~A})$, whereby the distracters have a more detrimental effect on performance in the High PD group.

There was also a three way interaction between participant group, Stimuli and Group (F(1.16, 63.61 $=4.76, p=0.028$, Figure 1B). There was a greater effect of distracters on the AX stimuli in the High PD group.

\section{INSERT FIGURE 1 ABOUT HERE.}




\section{Reaction Time}

In Table 4 the estimated marginal means (standard errors) are shown for the reaction time data from the AX-BY CPT.

\section{Main effects of Task}

There were significant effects of stimuli being longest for BX stimuli and shortest for the BY stimuli $(\mathrm{F}(2.44,134.40)=47.96, \mathrm{p}<0.001 ; \mathrm{AX}: 539.02$ (15.95); BY: 508.77 (15.84); BX: 685.48 (23.71); AY: 586.43 (18.80)). The presence of distracters led to significantly longer reaction times than when they were not present $(\mathrm{F}(1,55)=5.45, \mathrm{p}=0.023$; Distracter: 591.87 (14.11); No Distracter: 567.99 (17.03)).

\section{Effects of Participant Groups}

There was no main effect or interactions with participant group on reaction time.

\section{iv. Trial and Error Task}

For the trial and error task, a repeated measures ANOVA was used with two within subject variables: 5 levels of task block (to examine effects of learning) and two levels of stimuli type, either pair or non-pair. Estimated marginal means and standard errors are reported.

\section{Accuracy}

Main Effect of Task 
There were significant effects of the task with participants learning over the course of the five blocks (Block1: 0.54 (0.01); Block 2: 0.58 (0.01); 0.61 (0.02); Block 4: 0.65 (0.02); Block 5: $0.64(0.02) ; \mathrm{F}(3.48,257.69)=14.81, \mathrm{p}<0.001)$, overall participants learnt to identify the pairs $(0.66(0.01))$ better than the non-pairs $(0.55(0.02) ; \mathrm{F}(1.00,74.00)=44.45, \mathrm{p}<0.001)$ and an interaction between learning over the five blocks and the type of stimuli $(\mathrm{F}(2.62$, 195.23) $=14.95, \mathrm{p}<0.001)$, the rate of learning for the non-pairs (Block1: $0.42(0.02)$; Block 2: 0.50 (0.02); 0.56 (0.03); Block 4: 0.69 (0.02); Block 5: 0.58 (0.03)) appears to be more consistent than the pairs (Block1: 0.68 (0.02); Block 2: 0.65 (0.02); 0.67 (0.02); Block 4: 0.60 (0.03); Block 5: $0.71(0.02))$.

\section{Effects of Participant Group}

For the total number correct there were no effects or interactions with participant group.

\section{Response Time}

Main Effect of Task

For the reaction time similarly, there were significant effects of task block $(\mathrm{F}(1.27$, $93.84)=22.89)$, type of stimuli $(\mathrm{F}(1.00,74.00)=5.60, \mathrm{p}=0.012$ and an interaction between learning over the five blocks and the type of stimuli $(\mathrm{F}(1.29,95.09)=15.47, \mathrm{p}<0.001)$.

\section{Effects of Participant Groups}

However, there were also significant effects of the participant group $(F(1,74)=7.56, p=0.035)$ and an interaction between task block and group $(\mathrm{F}(1.27,93.84)=2.92, \mathrm{p}=0.012)$ (see Figures 
Are deficits in cognition associated with psychotic-like experiences after cannabis?

$2 \mathrm{a}$ and $2 \mathrm{~b}$ ). Follow up t-tests demonstrated that there were significant differences between the two groups at all and between blocks ( $\mathrm{p}$ values between 0.029 and 0.05 ) with the exception of Blocks 3 and 5 for Pairs and Block 5 for Non-Pairs. The High PD group were consistently faster at responding to the task.

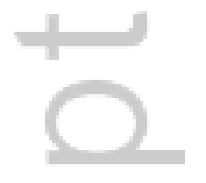

[15

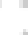

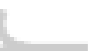

\section{Discussion:}

This paper asks whether cognitive factors differentiate between people who have psychoticlike experiences after cannabis compared from those who have primarily euphoric experiences. We hypothesised that those who reported psychotic-like experiences after cannabis would have reduced cognitive performance. However, the results were much more subtle than we first supposed. Indeed on the measure of spatial working memory, those with psychotic-like experiences appeared to have a more efficient way of completing the medium difficulty level of the task; although on examination of the means, despite not being significant, they required more selections for the easiest and most challenging levels. On response times those with psychosis/dysphoric experiences after cannabis had shorter response times on the trial and error learning task. Further, on the CPT, those with psychosis/dysphoric experiences were significantly more perturbed by the presence of the distracters in regards to their accuracy. 
There were no significant differences between the two groups on the schizotypy measure included. This may seem surprising, however, previous studies (e.g. Barkus and Lewis 2008) report that higher schizotypy scores are associated with elevated scores on both Euphoric and Psychosis-Dysphoric subscales from the CEQ. This would point to those scoring higher on schizotypy as being more sensitive to cannabis rather than necessarily just prone to the psychotogenic effects of the drug. Consequently, participant selection which emphasized reporting euphoric experiences for the control group may have led to some individuals who score higher on schizotypy in the controls. By contrast had we selected control participants who reported few subjective effects after cannabis, there may have been greater separation on schizotypy scores. However, it does appear that those who experience Psychosis-Dysphoric immediate effects also report more after effects from cannabis use; not just a persistence in the psychosis-like experiences but also the reduced motivation and lack of attention typically characterising the amotivational state. The significance of after effects from cannabis use is worthy of further investigation. The groups also did not differ significantly on demographic, verbal intelligence, verbal fluency or processing speed. This suggests deficits in these basic cognitive capacities cannot explain the other cognitive differences reported.

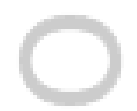

This paper demonstrates that it is possible to specifically select a group of people who display a propensity towards psychosis/dysphoric experiences after cannabis and differentiate them from those who experience primarily euphoric effects on aspects of cognitive performance. There were no differences between our two groups in exposure to other recreational drugs, intelligence or processing speed. Using the CEQ, we ask participants to report the 
Are deficits in cognition associated with psychotic-like experiences after cannabis?

experiences they specifically attribute to their cannabis use. Of course it is not possible to rule out multiple recreational drugs being consumed in one session. However, the questionnaire asks how frequently they have the experiences when using cannabis specifically. Therefore high scores reflect experiences which occur regularly when using cannabis. Those who had the psychosis/dysphoric experiences after cannabis reported poorer performance when faced with additional cognitive load and faster response times during trial and error learning. The shorter response times in the trial and error task may be related to the ambiguous nature of the task. It has been demonstrated that under conditions of uncertainty, otherwise healthy individuals with a propensity for unusual thoughts and beliefs demonstrate data gathering biases which mean they make decisions more rapidly (Menon et al 2013; Zawadzki et al 2012; Freeman et al 2008).

Previous research has reported that regular cannabis users activate brain regions used for attentional or executive control even whilst completing only a relatively simple visuomotor task (King et al 2011). This suggests relative inefficiency in the processing of visual information. Those who report the psychosis/dysphoric experiences seem to display a hypersensitivity to the effects of cannabis. Consequently they may be more sensitive to the detrimental effects of cannabis use on cognitive performance. A complementary hypothesis, and that postulated here, is that inefficient cognitive processes are part of the phenotype which predisposes people to psychosis/dysphoric experiences after cannabis. The cannabis use therefore perturbs an already inefficient system reducing performance further. The primary psychoactive ingredient in cannabis $\Delta-9-\mathrm{THC}$ has been associated with reduced 
cognitive performance in healthy volunteers when administered acutely (Englund et al 2013; Morrison et al 2009; D’Souza et al 2008; Ranganathan and D'Souza 2006; D'Souza et al 2004). The reduced cognitive performance has been reported to be further exacerbated by pre-treatment with haloperidol, a potent dopamine antagonist (D'Souza et al 2008). The role of dopamine receptor 1 (DR1) in working memory has been well documented (e.g. Sawaguchi and Goldman-Rakic 1991) and holds relevance for the continuous performance task performance here. In humans, administration of $\Delta-9-\mathrm{THC}$ has been shown to lead to increased dopamine release in some (e.g. Bossong et al 2009) but not all studies (Barkus et al 2011; Stokes et al 2009). Additionally, many of the $\Delta$-9-THC studies cited report no relationship between the psychotomimetic effects of $\Delta-9-\mathrm{THC}$ and reduced cognition performance, nor consistently report links between dopamine release and psychotic experiences. Therefore the relationship between $\Delta-9-\mathrm{THC}$ and dopamine does not appear to be straight forward, making it difficult to draw conclusions concerning the neuromodulator vulnerabilities in those who report psychosis/dysphoric experiences after cannabis. Dopamine pathways do look like an attractive mechanism. However, to date the evidence for a relationship between $\Delta-9-\mathrm{THC}$ and dopamine release, and their subsequent relationship to cognitive deficits, are poorly understood.

That we can move from these differences in cognitive performance to experiences reported after cannabis does have some precedent in the literature. Recently, Atakan et al (2013) reported that healthy volunteers who reported psychotic-like experiences after $\Delta$-9-THC administration, demonstrated reduced performance on an inhibition task as well as a 
Are deficits in cognition associated with psychotic-like experiences after cannabis?

differential functional imaging signature in the parahippocampal gyrus, left and right middle temporal gyri and right cerebellum. From a neuroanatomical perspective, methamphetamine sensitisation in rodents has been reported to increase the number of high affinity DR1 and DR2 (Shuto et al 2008). Therefore, it is possible that repeated use of cannabis in humans may lead to similar neuroanatomical changes (although see Albrecht et al 2013). Given the complex interactions between the cannabinoid and dopamine systems, where modulation of one can take place through activation of the other (Rodríguez De Fonseca et al 2001), whether sensitising effects of cannabis are on the dopamine or cannabinoid system may become a moot point (see Gorriti et al 1999). However, the identification of the beginning of the cascade of neurobiological events which underpin cannabis-induced psychosis would assist in determining targeted pharmacological treatments as well as, perhaps, differentiate these patients from others who carry the label of a psychotic disorder.

There are a number of limitations to the current study. The sample size is relatively small given that we would not expect effect sizes to be large within this area. This could have accounted for the lack of significant differences between the two groups. Although there were no significant differences between the two groups for demographic variables such as sex and age, we know that these can have effects on cognitive performance. To date we have not found biological reasons why sex would lead to differences in the experiences people report after cannabis. However, it is possible that sex may still have been a confounding variable which we need to consider as a covariate in future studies. The links between cannabis experiences and the neurobiological underpinnings presented in the discussion are purely 
speculative. Whilst there are documented links between certain neurocognitive processes and neurotransmission, the neurobiological effects of cannabis are still a matter of debate.

Consequently we can only surmise on the basis of existing evidence what the mechanism may be which underpins individual differences in the subjective experiences after cannabis.

This paper presented data which suggests that individual variation in responses after cannabis may be mediated by both cognitive, and ultimately, biologically meaningful individual differences. Particularly in the domains of sustained attention, under conditions where the cognitive load is increased. The measurement of individual differences in responses to cannabis provides a window into other subtle differences in cognitive performance which, in turn, are linked to neurobiological systems implicated in schizophrenia. The results presented here require replication in a larger sample. However, there is an accumulation of evidence that individual responses to cannabis are informative. Future studies should also consider using an additional group of participants who report few if any subjective effects after smoking cannabis to determine whether these individuals are a distinct cluster.

\section{References:}

Albrecht DS, Skosnik PD, Vollmer JM, Brumbaugh MS, Perry KM, Mock BH, Zheng QH, Federici LA, Patton EA, Herring CM, Yoder KK. 2013. Striatal D(2)/D(3) receptor availability is inversely correlated with cannabis consumption in chronic marijuana users. Drug Alcohol Depend 128(1-2):52-7. doi: 10.1016/j.drugalcdep.2012.07.016. 
Are deficits in cognition associated with psychotic-like experiences after cannabis?

Alemany S, Arias B, Fatjó-Vilas M, Villa H, Moya J, Ibáñez MI, Ortet G, Gastó C, Fañanás

L. 2014. Psychosis-inducing effects of cannabis are related to both childhood abuse and COMT genotypes. Acta Psychiatr Scand. 129(1):54-62. doi: 10.1111/acps.12108.

Atakan Z, Bhattacharyya S, Allen P, Martín-Santos R, Crippa JA, Borgwardt SJ, Fusar-Poli P, Seal M, Sallis H, Stahl D, Zuardi AW, Rubia K, McGuire P. 2013. Cannabis affects people differently: inter-subject variation in the psychotogenic effects of $\Delta 9$-tetrahydrocannabinol: a functional magnetic resonance imaging study with healthy volunteers. Psych Med 43(6):1255-67. doi: 10.1017/S0033291712001924.

Barkus E, Morrison PD, Vuletic D, Dickson JC, Ell PJ, Pilowsky LS, Brenneisen R, Holt DW, Powell J, Kapur S, Murray RM. 2011. Does intravenous $\Delta$ 9-tetrahydrocannabinol increase dopamine release? A SPET study. J Psychopharm 25(11):1462-8. doi: $10.1177 / 0269881110382465$.

Barkus E, Lewis S. 2008. Schizotypy and psychosis-like experiences from recreational cannabis in a non-clinical sample. Psych Med 38(9):1267-76. doi:

$10.1017 / \mathrm{S} 0033291707002619$.

Barkus EJ, Stirling J, Hopkins RS, Lewis S. 2006. Brief report: Cannabis-induced psychoticlike experiences are associated with high schizotypy. Psychopathology 39:175-178. 
Bossong MG, van Berckel BNM, Boellaard R, Zuurman L, Schuit RC, Windhorst AD, van Gerven JMA, Ramsey NF, Lammertsma AA, Kahn RS. 2009. A9-Tetrahydrocannabinol Induces Dopamine Release in the Human Striatum. Neuropsychopharmacology 34:759-766. doi: $10.1038 / \mathrm{npp} .2008 .138$.

Callicot JH, Ramsey NF, Talent K, Bertolino A, Knable MB, Coppola R, Goldberg T, van Gelderen P, Mattay VS, Frank JA, Moonen CT, Weinberger DR. 1998. Functional magnetic resonance imaging brain mapping in psychiatry: metholodogical issues illustrated in a study of working memory in schizophrenia. Neuropsychopharmacology 18(3):186-196.

Davidson ES, Schenk S. 1994. Variability in subjective responses to marijuana: initial experiences of college students. Addict Behav 19(5):531-8.

Diwadkar VA, Montrose DM, Dworakowski D, Sweeney JA, Keshavan MS. 2006.

Genetically predisposed offspring with schizotypal features: an ultra high-risk group for schizophrenia? Prog Neuropsychopharmacol Biol Psychiatry 30(2):230-238.

D'Souza DC, Braley G, Blaise R, Vendetti M, Oliver S, Pittman B, Ranganathan M, Bhakta S, Zimolo Z, Cooper T, Perry E. 2008. Effects of haloperidol on the behavioral, subjective, cognitive, motor, and neuroendocrine effects of Delta-9-tetrahydrocannabinol in humans. Psychopharmacology (Berl) 198(4):587-603. doi: 10.1007/s00213-007-1042-2. 
Are deficits in cognition associated with psychotic-like experiences after cannabis?

D'Souza DC, Perry E, MacDougall L, Ammerman Y, Cooper T, Wu YT, Braley G, Gueorguieva R, Krystal JH. 2004. The psychotomimetic effects of intravenous delta-9tetrahydrocannabinol in healthy individuals: implications for psychosis.

Neuropsychopharmacology 29(8):1558-72.

Englund A, Morrison PD, Nottage J, Hague D, Kane F, Bonaccorso S, Stone JM, Reichenberg A, Brenneisen R, Holt D, Feilding A, Walker L, Murray RM, Kapur S. 2013. Cannabidiol inhibits THC-elicited paranoid symptoms and hippocampal-dependent memory impairment. J Psychopharmacol 27(1):19-27. doi: 10.1177/0269881112460109.

Freeman D, Pugh K, Garety P. 2008 Jumping to conclusions and paranoid ideation in the general population. Schizophr Res 102(1-3):254-60. doi: 10.1016/j.schres.2008.03.020.

Gorriti MA, Rodríguez de Fonseca F, Navarro M, Palomo T. 1999. Chronic delta9tetrahydrocannabinol treatment induces sensitization to the psychomotor effects of amphetamine in rats. Euro J Pharmacol 365(2-3):133-42.

Henquet C, Rosa A, Krabbendam L, Papiol S, Fananás L, Dukker M, Ramaekers JG, van Os J. 2006. An experimental study of catechol-o-methyltransferase Val158Met moderation of delta-9-tetrehydrocannabinol-induced effects on psychosis and cognition. Neuropsychopharm 31(12):2748-2757. 
Hides L, Lubman DI, Buckby J, Yuen HP, Cosgrave E, Baker K, Yung AR. 2009. The association between early cannabis use and psychotic-like experiences in a community adolescent sample. Schizophr Res 112(1-3):130-5. doi: 10.1016/j.schres.2009.04.001.

Indlekofer F, Piechatzek M, Daamen M, Glasmacher C, Lieb R, Pfister H, Tucha O, Lange KW, Wittchen HU, Schütz CG. 2009. Reduced memory and attention performance in a population-based sample of young adults with a moderate lifetime use of cannabis, ecstasy and alcohol. J Psychopharm 23(5):495-509. doi: 10.1177/0269881108091076.

Johnson JK, Tuulio-Henriksson A, Pirkola T, Huttunen MO, Lönnqvist J, Kaprio J, Cannon TD. 2003. Do schizotypal symptoms mediate the relationship between genetic risk for schizophrenia and impaired neuropsychological performance in co-twins of schizophrenic patients? Biol Psychiatry 54(11):1200-4.

Keshavan M, Montrose DM, Rajarethinam R, Diwadkar V, Prasad K, Sweeney JA. 2008. Psychopathology among off spring of parents with schizophrenia: relationship to premorbid impairments. Schizophr Res 103(1-3):114-120. doi: 10.1016/j.schres.2008.03.006.

King GR, Ernst T, Deng W, Stenger A, Gonzales RM, Nakama H, Chang L. 2011. Altered rain activation during visuomotor integration in chronic active cannabis users: relationship to cortisol levels. J Neurosci 31(49):17923-31. doi: 10.1523/JNEUROSCI.4148-11.2011. 
Are deficits in cognition associated with psychotic-like experiences after cannabis?

Lenzenweger MF, Gold JM. 2000. Auditory working memory and verbal recall memory in schizotypy. Schizophr Res 42(2):101-10.

Mackie CJ, Castellanos-Ryan N, Conrod PJ. 2011. Developmental trajectories of psychoticlike experiences across adolescence: impact of victimization and substance use. Psychol Med 41(1):47-58. doi: 10.1017/S0033291710000449.

Mason O, Morgan CJ, Stefanovic A, Curran HV. 2009. The psychotomimetic states inventory (PSI): measuring psychotic-type experiences from ketamine and cannabis. Schizophr Res 103(1-3):138-142. doi: 10.1016/j.schres.2008.02.020.

Mass R, Bardong C, Kindl K, Dahme B. 2001. Relationship between cannabis use, schizotypal traits, and cognitive function in healthy subjects. Psychopathology 34(4):209-14.

McHale S, Hunt N. 2008. Executive function deficits in short-term abstinent cannabis users. Hum Psychopharmacol 23(5):409-15. doi: 10.1002/hup.941.

Mehta MA, Hinton EC, Montgomery AJ, Bantick RA, Grasby PM. 2005. Sulpride and mnemonic function: effects of a dopamine D2 receptor antagonist on working memory, emotional memory and long-term memory in healthy volunteers. J Psychopharmacol 19(1):29-38. 
Menon M, Quilty LC, Zawadzki JA, Woodward TS, Sokolowski HM, Boon HS, Wong AH. 2013. The role of cognitive biases and personality variables in subclinical delusional ideation. Cogn Neuropsychiatry 18(3):208-18. doi: 10.1080/13546805.2012.692873.

Morrison PD, Zois V, McKeown DA, Lee TD, Holt DW, Powell JF, Kapur S, Murray RM.

2009. The acute effects of synthetic intravenous Delta9-tetrahydrocannabinol on psychosis, mood and cognitive functioning. Psychol Med 39(10):1607-16. doi:

10.1017/S0033291709005522.

Ranganathan M, D'Souza DC. 2006. The acute effects of cannabinoids on memory in humans: a review. Psychopharmacology (Berl). 188(4):425-44.

Rodríguez De Fonseca F, Gorriti MA, Bilbao A, Escuredo L, García-Segura LM, Piomelli D, Navarro M. 2001. Role of the endogenous cannabinoid system as a modulator of dopamine transmission: implications for Parkinson's disease and schizophrenia. Neurotox Res 3(1):2335.

Rössler W, Riecher-Rössler A, Angst J, Murray R, Gamma A, Eich D, van Os J, Gross VA. 2007. Psychotic experiences in the general population: a twenty-year prospective community study. Schizophr Res 92(1-2):1-14. 
Are deficits in cognition associated with psychotic-like experiences after cannabis?

Ruiz-Veguilla M, Barrigón ML, Hernández L, Rubio JL, Gurpegui M, Sarramea F, Cervilla J, Gutiérrez B, James A, Ferrin M. 2013. Dose-response effect between cannabis use and psychosis liability in a non-clinical population: evidence from a snowball sample. J Psychiatr Res 47(8):1036-43. doi: 10.1016/j.jpsychires.2013.03.003.

Shuto T, Seeman P, Kuroiwa M, Nishi A. 2008. Repeated administration of a dopamine D1 receptor agonist reverses the increased proportions of striatal dopamine D1High and D2High receptors in methamphetamine-sensitized rats. Euro J Neurosci 27(10):2551-7. doi:10.1111/j.1460-9568.2008.06221.x

Smallman RP, Barkus E, Rushe TM. 2009. Age and gender effects on schizotypy and cognitive function. Schizophrenia Bulletin, 35(Supplement1), 283.

Solowij N, Michie PT. 2007. Cannabis and cognitive dysfunction: parallels with endophenotypes of schizophrenia? J Psychiatry Neurosci 32(1):30-52.

Solowij N, Stephens RS, Roffman RA, Babor T, Kadden R, Miller M, Christiansen K, McRee B, Vendetti J; Marijuana Treatment Project Research Group. 2002. Cognitive functioning of long-term heavy cannabis users seeking treatment. JAMA 287(9):1123-31.

Stefanis NC, Delespaul P, Smyrnis N, Lembesi A, Avramopoulos DA, Evdokimidis IK, Stefanis CN, van Os J. 2004. Is the excess of psychosis-like experiences in urban areas 
attributable to altered cognitive development? Soc Psychiatry Psychiatr Epidemiol 39(5):364368.

Stirling J, Barkus EJ, Nabosi L, Irshad S, Roemer G, Schreudergoidheijt B, Lewis, S. 2008. Cannabis-induced psychotic-like experiences are predicted by high schizotypy: confirmation of preliminary results in a large cohort. Psychopathology 41:371-378.

doi:10.1159/000155215

Stokes PR, Mehta MA, Curran HV, Breen G, Grasby PM. 2009. Can recreational doses of THC produce significant dopamine release in the human striatum? Neuroimage 48(1):186-90. doi: 10.1016/j.neuroimage.2009.06.029.

Suhr JA, Spitznagel MB. 2001. Factor versus cluster models of schizotypal traits. II: relation to neuropsychological impairment. Schizophr Res 52(3):241-50.

Sawaguchi T, Goldman-Rakic PS. 1991. D1 dopamine receptors in prefrontal cortex: involvement in working memory. Science 251(4996):947-950 doi: 10.1126/science.1825731

Van Os J, Bak M, Hanssen M, Bijl RV, de Graaf R, Verdoux H. 2002. Cannabis use and psychosis: a longitudinal population-based study. Am J Epidemiol 156 (4):319-327. doi: 10.1093/aje/kwf043

This article is protected by copyright. All rights reserved. 
Are deficits in cognition associated with psychotic-like experiences after cannabis?

Verdoux H, Gindre C, Sorbara F, Tournier M, Swendsen JD. 2003. Effects of cannabis and psychosis vulnerability in daily life: an experience sampling test study. Psychol Med 33(1):23-32

Woods SW, Addington J, Cadenhead KS, Cannon TD, Cornblatt BA, Heinssen R, Perkins DO, Seidman LJ, Tsuang MT, Walker EF, McGlashan TH. 2009. Validity of the prodromal risk syndrome for first psychosis: findings from the North American Prodrome Longitudinal Study. Schizophr Bull 35(5):984-908. doi: 10.1093/schbul/sbp027.

Zawadzki JA, Woodward TS, Sokolowski HM, Boon HS, Wong AH, Menon M. 2012.

Cognitive factors associated with subclinical delusional ideation in the general population. Psychiatry Res 197(3):345-9. doi: 10.1016/j.psychres.2012.01.004.

This article is protected by copyright. All rights reserved. 
Cannabis experiences and cognition.

Table 1: Descriptive characteristics for participants groups (\%, means (SDs)).

\begin{tabular}{|c|c|c|}
\hline & High PD $(n=40)$ & Controls $(n=36)$ \\
\hline $\begin{array}{l}\text { Demographics } \\
\text { Age (years) } \\
\text { Sex } \\
\text { Age of first cannabis use (years) }\end{array}$ & $\begin{array}{l}26.25(5.21) \\
55 \% \text { female } \\
16.05(2.88)\end{array}$ & $\begin{array}{l}28.08(8.62) \\
56 \% \text { female } \\
16.08(2.03)\end{array}$ \\
\hline $\begin{array}{l}\text { Relationship Status } \\
\text { Single } \\
\text { Steady Relationship } \\
\text { Married/living with someone } \\
\text { Widowed }\end{array}$ & $\begin{array}{r}45 \% \\
45 \% \\
10 \% \\
-\end{array}$ & $\begin{array}{c}61 \% \\
22 \% \\
14 \% \\
3 \%\end{array}$ \\
\hline $\begin{array}{l}\text { Employment } \\
\text { Student } \\
\text { Part time employed } \\
\text { Full time employed } \\
\text { Self employed } \\
\text { Unemployed }\end{array}$ & $\begin{array}{c}23 \% \\
8 \% \\
48 \% \\
8 \% \\
15 \%\end{array}$ & $\begin{array}{c}33 \% \\
8 \% \\
36 \% \\
7 \% \\
17 \%\end{array}$ \\
\hline $\begin{array}{l}\text { Cannabis Use Status } \\
\text { Current user } \\
\text { Past user }\end{array}$ & $\begin{array}{l}43 \% \\
58 \%\end{array}$ & $\begin{array}{l}54 \% \\
46 \%\end{array}$ \\
\hline $\begin{array}{l}\text { Frequency of Cannabis use } \\
\text { Everyday } \\
\text { More than once a week } \\
\text { About once a week } \\
\text { About once or twice a month } \\
\text { A few times a year } \\
\text { About once a year } \\
\text { Only once or twice } \\
\end{array}$ & $\begin{array}{c}31 \% \\
17 \% \\
6 \% \\
17 \% \\
17 \% \\
7 \% \\
3 \% \\
\end{array}$ & $\begin{array}{c}24 \% \\
33 \% \\
9 \% \\
15 \% \\
9 \% \\
6 \% \\
3 \% \\
\end{array}$ \\
\hline $\begin{array}{l}\text { Social Context of most use } \\
\text { Socially } \\
\text { On own } \\
\text { Other }\end{array}$ & $\begin{array}{c}85 \% \\
15 \% \\
- \\
\end{array}$ & $\begin{array}{c}81 \% \\
14 \% \\
6 \%\end{array}$ \\
\hline $\begin{array}{l}\text { Time of day of use } \\
\text { During the day } \\
\text { During the evening } \\
\text { Frequently during the day and evening }\end{array}$ & $\begin{array}{c}- \\
85 \% \\
15 \%\end{array}$ & $\begin{array}{c}6 \% \\
86 \% \\
8 \%\end{array}$ \\
\hline $\begin{array}{l}\text { Amount spent on cannabis per week } \\
\text { Less than } £ 2.50 \\
£ 2.50-£ 5 \\
£ 5-£ 10 \\
£ 10-£ 15 \\
£ 15-£ 20 \\
\text { Above } £ 20\end{array}$ & $\begin{array}{c}48 \% \\
10 \% \\
15 \% \\
5 \% \\
10 \% \\
13 \%\end{array}$ & $\begin{array}{c}42 \% \\
11 \% \\
19 \% \\
3 \% \\
19 \% \\
7 \% \\
\end{array}$ \\
\hline $\begin{array}{l}\text { Cannabis Experiences Questionnaire (CEQ) } \\
\text { Euphoric } \\
\text { Paranoid-Dysphoric*** } \\
\text { Amotivational After Effects*** } \\
\text { Psychosis-like After Effects*** }\end{array}$ & $\begin{array}{c}42.63(9.78) \\
59.08(12.12) \\
19.60(6.13) \\
8.98(3.11)\end{array}$ & $\begin{array}{l}39.25(8.56) \\
36.25(7.71) \\
14.36(5.63) \\
5.89(1.63)\end{array}$ \\
\hline
\end{tabular}


Are deficits in cognition associated with psychotic-like experiences after cannabis?

\begin{tabular}{|l|c|c|}
\hline Schizotypal Personality Questionnaire (SPQ) & & \\
Cognitive Perceptual & $11.15(8.27)$ & $10.50(11.74)$ \\
Interpersonal & $11.68(8.22)$ & $10.94(9.79)$ \\
Disorganisation & $6(3.90)$ & $6.11(4.83)$ \\
Total & $26.10(14.84)$ & $22.11(22.54)$ \\
\hline
\end{tabular}

$* * * \mathrm{p}<0.001$

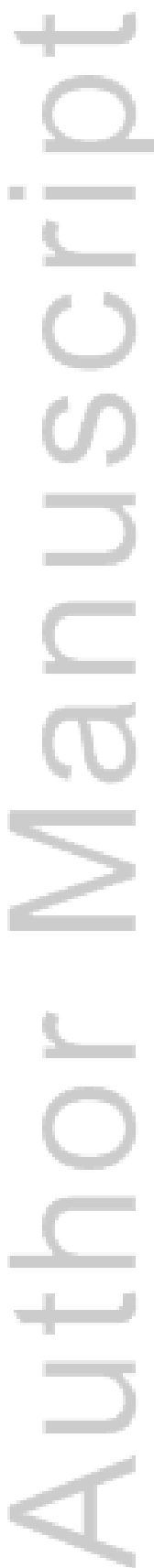

This article is protected by copyright. All rights reserved. 
Cannabis experiences and cognition.

Table 2: The use of other recreational drugs, alcohol and nicotine in the whole sample $(\mathrm{N}=76)$.

\begin{tabular}{|c|c|c|c|c|c|c|c|}
\hline Drug & Age first & Ever & Current & \multicolumn{2}{|c|}{ Frequency of use (\%) } & \multicolumn{2}{|c|}{ When used (\%) } \\
\hline Alcohol & $\begin{array}{l}14(2) \\
\text { years }\end{array}$ & 95 & 94 & $\begin{array}{l}\text { Everyday } \\
\text { More than once a week } \\
\text { Few times each week }\end{array}$ & $\begin{array}{c}7 \\
63 \\
31\end{array}$ & $\begin{array}{c}\text { Evening } \\
\text { Day\&Evening }\end{array}$ & $\begin{array}{l}61 \\
39\end{array}$ \\
\hline Mushroom: & $\begin{aligned} & 19(3) \\
& \text { years }\end{aligned}$ & 32 & 17 & $\begin{array}{l}\text { Few times each week } \\
\text { Few times each year } \\
\text { Only once or twice }\end{array}$ & $\begin{array}{c}4 \\
21 \\
75\end{array}$ & $\begin{array}{c}\text { Daytime } \\
\text { Evening } \\
\text { Day\&Evening }\end{array}$ & $\begin{array}{l}18 \\
50 \\
31\end{array}$ \\
\hline Nicotine & $\begin{array}{l}16(3) \\
\text { years }\end{array}$ & 71 & 43 & $\begin{array}{l}\text { Everyday } \\
\text { More than once a week } \\
\text { Few times each week } \\
\text { Few times each year } \\
\text { Only once or twice }\end{array}$ & $\begin{array}{c}52 \\
19 \\
11 \\
11 \\
7 \\
\end{array}$ & $\begin{array}{c}\text { Evening } \\
\text { Day\&Evening }\end{array}$ & $\begin{array}{l}33 \\
65\end{array}$ \\
\hline Cocaine & $\begin{array}{l}21(5) \\
\text { years }\end{array}$ & 50 & 24 & $\begin{array}{l}\text { More than once a week } \\
\text { Few times each week } \\
\text { Few times each year } \\
\text { Only once or twice }\end{array}$ & $\begin{array}{c}3 \\
16 \\
55 \\
26\end{array}$ & $\begin{array}{c}\text { Daytime } \\
\text { Evening } \\
\text { Day\&Evening }\end{array}$ & $\begin{array}{l}30 \\
44 \\
12\end{array}$ \\
\hline Ecstasy & $\begin{array}{l}21(6) \\
\text { years }\end{array}$ & 41 & 38 & $\begin{array}{l}\text { More than once a week } \\
\text { Few times each week } \\
\text { Few times each year } \\
\text { Only once or twice }\end{array}$ & $\begin{array}{c}3 \\
10 \\
66 \\
21\end{array}$ & $\begin{array}{c}\text { Evening } \\
\text { Day\&Evening }\end{array}$ & $\begin{array}{l}82 \\
18\end{array}$ \\
\hline Amphetam & $\begin{array}{l}18(3) \\
\text { years }\end{array}$ & 20 & 0 & $\begin{array}{l}\text { Few times each week } \\
\text { Few times each year } \\
\text { Only once or twice }\end{array}$ & $\begin{array}{c}8 \\
15 \\
77\end{array}$ & $\begin{array}{c}\text { Evening } \\
\text { Day\&Evening }\end{array}$ & $\begin{array}{l}69 \\
31\end{array}$ \\
\hline MDMA & $\begin{array}{l}17(7) \\
\text { years }\end{array}$ & 15 & 64 & $\begin{array}{l}\text { More than once a week } \\
\text { Few times each week } \\
\text { Few times each year } \\
\text { Only once or twice }\end{array}$ & $\begin{array}{c}9 \\
27 \\
46 \\
18\end{array}$ & $\begin{array}{c}\text { Evening } \\
\text { Day\&Evening }\end{array}$ & $\begin{array}{l}60 \\
40\end{array}$ \\
\hline Ketamine & $\begin{array}{l}20(3) \\
\text { years }\end{array}$ & 15 & 18 & $\begin{array}{l}\text { Few times each year } \\
\text { Only once or twice }\end{array}$ & $\begin{array}{l}18 \\
82\end{array}$ & $\begin{array}{c}\text { Daytime } \\
\text { Evening } \\
\text { Day\&Evening }\end{array}$ & $\begin{array}{c}9 \\
72 \\
18\end{array}$ \\
\hline LSD & $\begin{array}{l}18(3) \\
\text { years }\end{array}$ & 13 & 21 & $\begin{array}{l}\text { Few times each week } \\
\text { Few times each year } \\
\text { Only once or twice }\end{array}$ & $\begin{array}{c}7 \\
43 \\
50\end{array}$ & $\begin{array}{c}\text { Evening } \\
\text { Day\&Evening }\end{array}$ & $\begin{array}{l}36 \\
64\end{array}$ \\
\hline Opium & $\begin{array}{c}24(11) \\
\text { years }\end{array}$ & 4 & 33 & $\begin{array}{l}\text { More than once a week } \\
\text { Only once or twice }\end{array}$ & $\begin{array}{l}33 \\
67\end{array}$ & $\begin{array}{c}\text { Daytime } \\
\text { Day\&Evening }\end{array}$ & $\begin{array}{l}33 \\
67\end{array}$ \\
\hline
\end{tabular}


Table 3: The significant effects for the number of choices the participants made on the SWM task and outcomes for nback.

\begin{tabular}{|c|c|c|c|}
\hline SWM - Choices & $\begin{array}{l}\text { Four Chests mean } \\
\text { (standard deviation) }\end{array}$ & $\begin{array}{l}\text { Six Chests* mean } \\
\text { (standard deviation) }\end{array}$ & $\begin{array}{l}\text { Eight Chests mean } \\
\text { (standard deviation) }\end{array}$ \\
\hline High PD $(n=40)$ & $7.29(1.05)$ & $14.24(1.89)$ & $17.78(5.53)$ \\
\hline Controls $(\mathrm{n}=35)$ & $7.15(0.66)$ & $15.50(1.35)$ & $16.69(4.31)$ \\
\hline Total Sample** & $7.23(0.89)$ & $14.83(1.77)$ & $17.27(5.00)$ \\
\hline \multicolumn{4}{|l|}{10} \\
\hline Nback & One back & Two back & Three back \\
\hline Correct response ${ }^{* *}$ & $8.84(0.53)$ & $8.33(1.01)$ & $7.07(1.44)$ \\
\hline $\begin{array}{l}\text { Correct response RT } \\
(\mathrm{ms})^{* *}\end{array}$ & $499.34(86.61)$ & $595.74(134.16)$ & 676.17 (157.24) \\
\hline Number of Errors** & $0.29(0.79)$ & $1.03(1.63)$ & $2.88(2.10)$ \\
\hline
\end{tabular}

Key: RT: Reaction time; * High PD and Controls differ significant at $\mathrm{p}<0.05$;** Main effect of task difficulty $\mathrm{p}<0.001$. 
Figure 1: The estimated marginal means and standard errors for the effects of A: The interaction between presence of a distracter and participant group; $\mathbf{B}$ : Stimuli, Distracter and Participant Group, for number of responses correct on the AX-BY CPT.

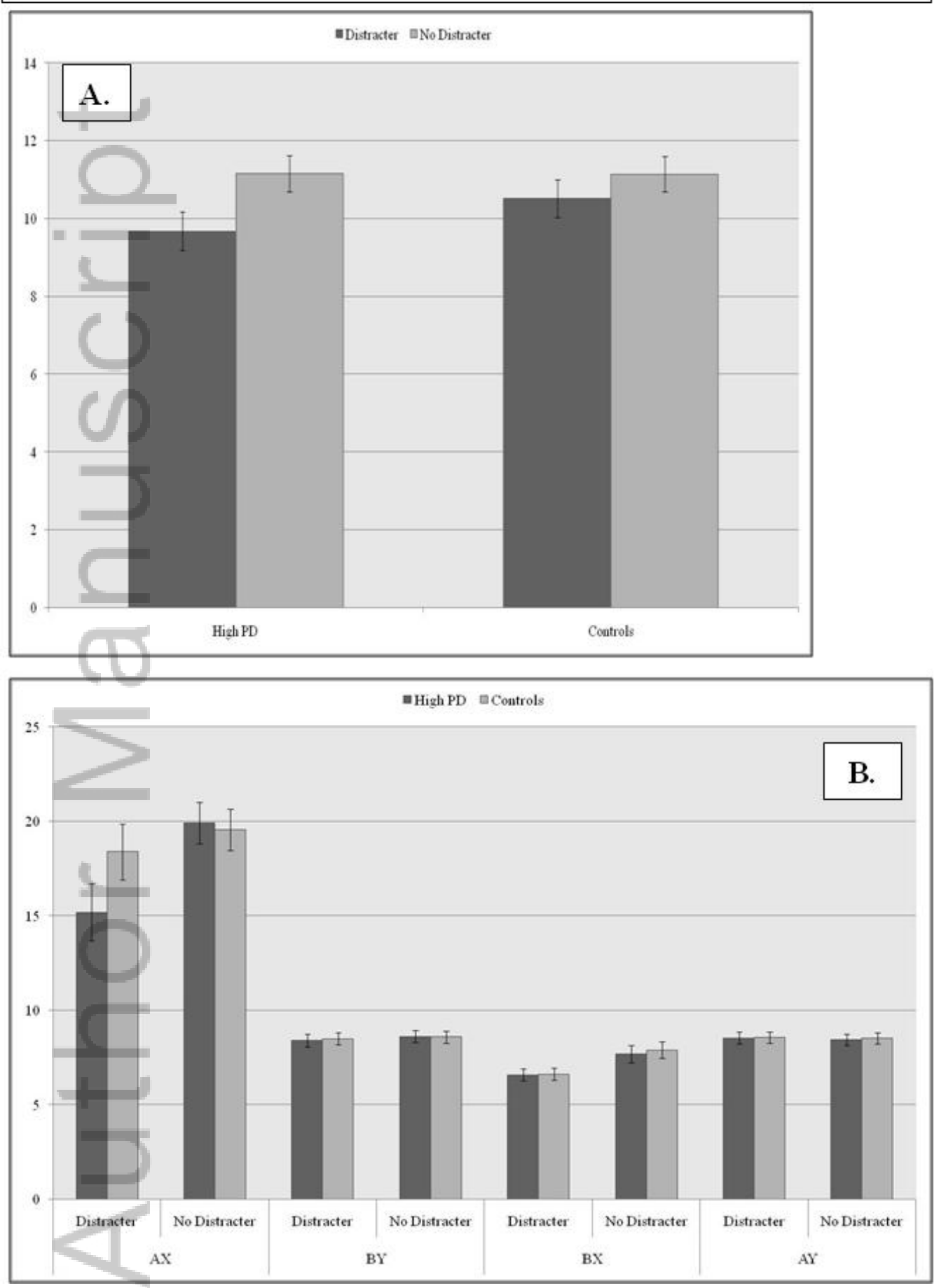


Are deficits in cognition associated with psychotic-like experiences after cannabis?

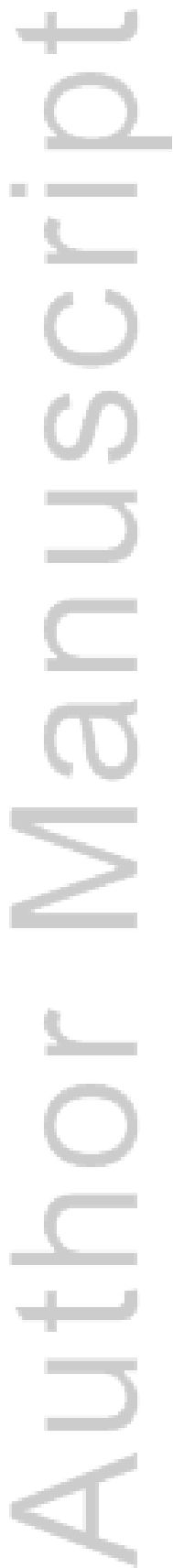

This article is protected by copyright. All rights reserved. 
Figure 2a: The response time for High PDs and Controls for the Correctly identified Pairs.

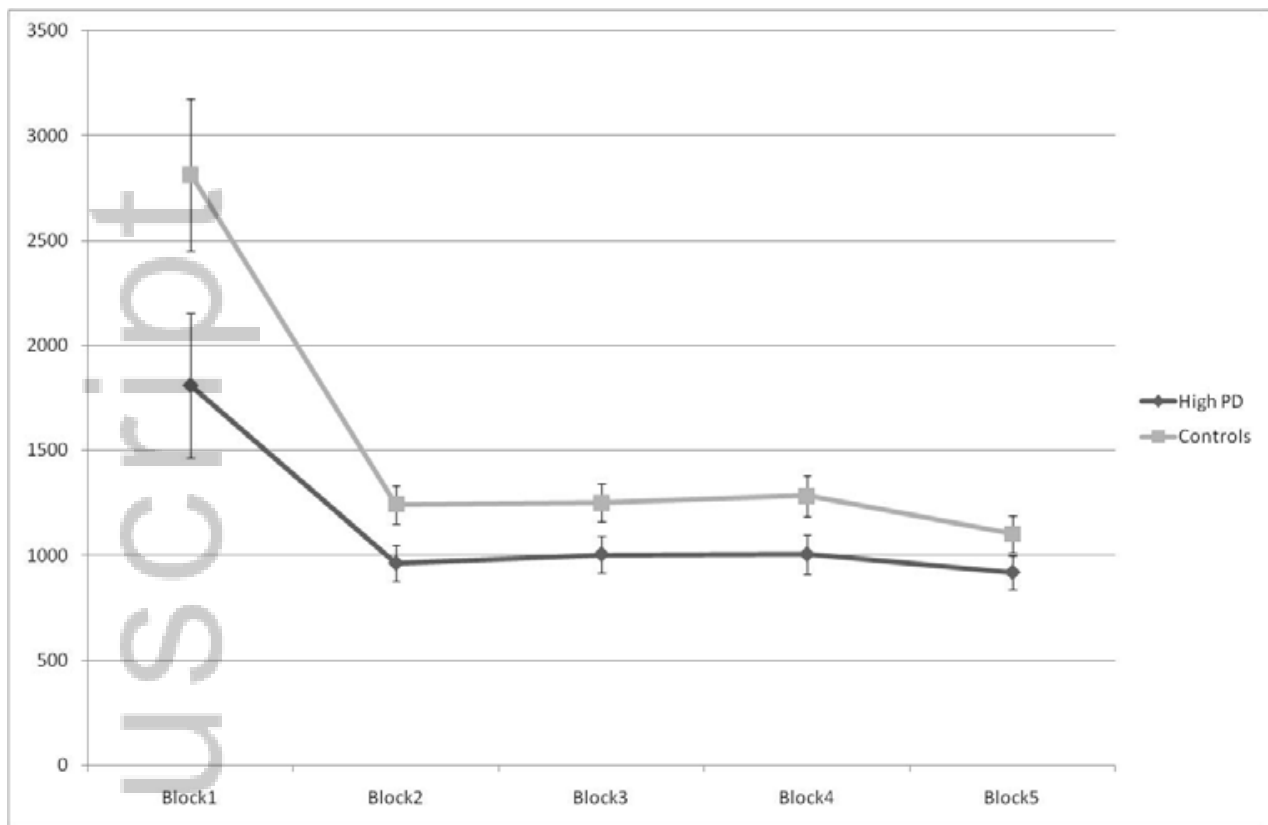

This article is protected by copyright. All rights reserved. 
Are deficits in cognition associated with psychotic-like experiences after cannabis?

Figure 2b: The response time for High PDs and Controls for the Correctly identified NonPairs.
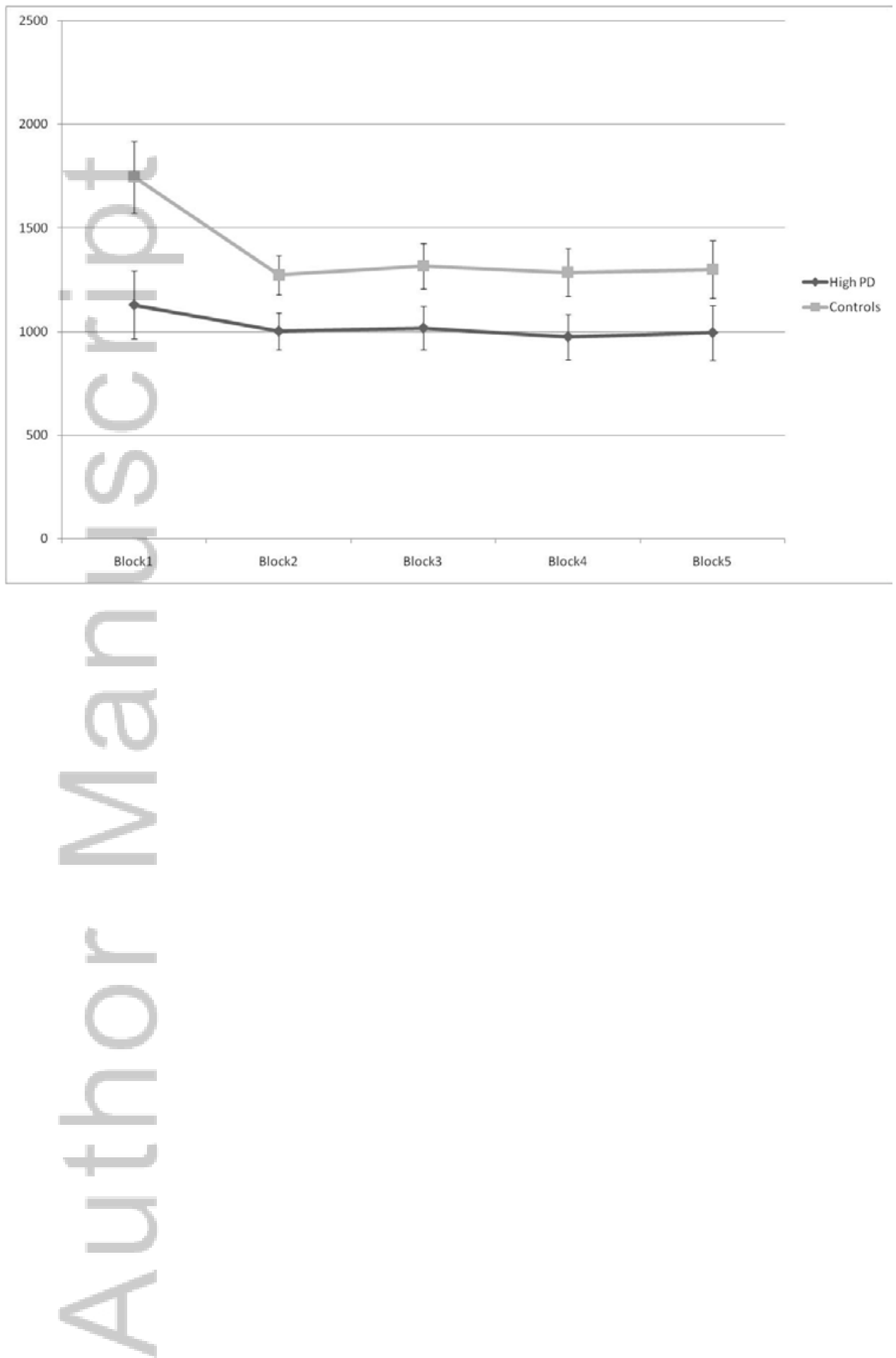

This article is protected by copyright. All rights reserved. 


\section{University Library}

\section{- M M I N E R VA A gateway to Melbourne's research publications}

Minerva Access is the Institutional Repository of The University of Melbourne

Author/s:

Barkus, E;Morrison, P;Di Forti, M;Murray, RM

Title:

Are deficits in cognition associated with psychotic-like experiences after cannabis?

Date:

2016-11

Citation:

Barkus, E., Morrison, P., Di Forti, M. \& Murray, R. M. (2016). Are deficits in cognition associated with psychotic-like experiences after cannabis?. Hum Psychopharmacol, 31 (6), pp.402-411. https://doi.org/10.1002/hup.2556.

Persistent Link:

http://hdl.handle.net/11343/292101 